\title{
Satellite-tracked movements of female Dermochelys coriacea from southeastern Brazil
}

\author{
Antonio P. Almeida ${ }^{1, *}$, Scott A. Eckert ${ }^{2}$, Soraya C. Bruno ${ }^{3}$, Juarez T. Scalfoni ${ }^{1}$, \\ Bruno Giffoni $^{4}$, Milagros López-Mendilaharsu ${ }^{5,6}$, João Carlos A. Thomé ${ }^{1}$ \\ ${ }^{1}$ Projeto TAMAR/ICMBio, Linhares, ES, CEP 29900-970, Brazil \\ ${ }^{2}$ Wider Caribbean Sea Turtle Conservation Network (WIDECAST), Ballwin, Missouri 63011, USA \\ ${ }^{3}$ Fundação Pró-TAMAR, Vitória, ES, CEP 29040-715, Brazil \\ ${ }^{4}$ Fundação Pró-TAMAR, Ubatuba, São Paulo, CEP 11680-000, Brazil \\ ${ }^{5}$ Fundação Pró-TAMAR, Salvador, BA, CEP 41815-135, Brazil \\ ${ }^{6}$ Programa de Pos-Graduação em Ecologia e Evolução, Departamento de Ecologia, IBRAG, \\ Universidade do Estado do Rio de Janeiro, RJ, CEP 20550-019, Brazil
}

\begin{abstract}
Four female leatherback sea turtles Dermochelys coriacea were satellite tracked from the southeastern coast of Brazil (3 from nesting beaches in the state of Espírito Santo, and 1 recovered from a driftnet off the coast of the state of São Paulo), representing the first study of movements of leatherbacks nesting on Brazilian grounds. The results suggest that during the internesting period, leatherbacks may disperse up to $160 \mathrm{~km}$ from the nesting beach using an area of $4400 \mathrm{~km}^{2}$. Tracking also revealed shared feeding areas in southern South America, comprising Brazilian, Uruguayan, and Argentinean waters, and highlighted important interactions with fisheries along nesting, migratory, and feeding habitats. The presence in migratory/foraging areas of turtles from at least 2 different nesting populations from both sides of the South Atlantic Ocean supports the concept that management efforts for this species must incorporate a broad regional perspective.
\end{abstract}

KEY WORDS: Dermochelys coriacea $\cdot$ Satellite telemetry $\cdot$ Migration $\cdot$ Internesting $\cdot$ Postnesting Atlantic Ocean

Resale or republication not permitted without written consent of the publisher

\section{INTRODUCTION}

Leatherback turtle Dermochelys coriacea nesting sites are spread over tropical and subtropical areas along all ocean basins (Spotila et al. 1996, Eckert 2006, Eckert et al. 2006, Thomé et al. 2007, Benson et al. 2007a, Fossette et al. 2008). Their pelagic habits, reinforced by several satellite telemetry studies, evidence a very broad distribution, reaching temperate and even sub-polar areas (Eckert 2006, James et al. $2006 a, b)$. Extensive migratory movements have been reported in the North Atlantic (Hays et al. 2004, James et al. 2005a,b, Eckert 2006, Eckert et al. 2006), eastern Pacific (Morreale et al. 1996, Spotila et al. 2000, Shillinger et al. 2008), western Pacific (Benson et al. 2007b), and Indian Oceans (Hughes et al. 1998, Luschi et al. 2003).

However, the conservation status of different populations varies: in the eastern Pacific Ocean, populations face strong declines, probably due to high rates of incidental captures in fisheries (Eckert \& Sarti 1997, Spotila et al. 2000, Martínez et al. 2007, Santidrián Tomillo et al. 2007) and poor foraging habitats (Saba et al. 2007, 2008). In contrast, the largest rookeries in the world are located in the Atlantic (Eckert 2006, Fretey et al. 2007, Girondot et al. 2007, Hilter- 
man \& Goverse 2007, Fossette et al. 2008), and stable or increasing trends have been reported (Dutton et al. 2005, Chacón-Chaverri \& Eckert 2007, Ordoñez et al. 2007), even in severely reduced nesting populations (Thomé et al. 2007).

Defining high-use habitat areas or pathways can help to understand the differences in the conservation status of different populations and guide the development of effective conservation efforts. In the South Atlantic, however, information regarding habitat use and migratory movements of leatherbacks is restricted to a few tag recoveries (Billes et al. 2006), a single study of foraging leatherbacks captured at sea (López-Mendilaharsu et al. 2009), and recent studies of postnesting movements from Gabon (Fossette et al. 2010, Witt et al. 2011). These studies documented transoceanic movements from nesting grounds in Africa to South America, and seasonal latitudinal movements of foraging leatherbacks between temperate and tropical high-use areas in South America. Particularly lacking is a study of leatherbacks from southwest Atlantic nesting beaches.

The nesting ground on the north coast of the state of Espírito Santo, southeastern Brazil (around 19 S), comprises the only known regularly used leatherback nesting site in Brazil (Fig. 1). The number of nests laid each year varies between 6 and 92 along a $160 \mathrm{~km}$ section of the coastline, with more than $90 \%$ of the nests located along the southernmost $80 \mathrm{~km}$ (Thomé et al. 2007). To manage this nesting area, the entire coastline is divided into $1 \mathrm{~km}$ patrol zones, numbered south to north; in the southern $37 \mathrm{~km}$, the area is protected under an Indigenous Land ( $\mathrm{km} \mathrm{1-}$ 23) and a Federal Conservation Unit (Reserva Biológica de Comboios, REBIO Comboios, km 23-37). The remaining area is mostly occupied by farming interspersed with a few villages located along the coast (Pontal do Ipiranga, km 92; Guriri, km 145; and Itaúnas, $\mathrm{km} \mathrm{159).} \mathrm{The} \mathrm{coastline} \mathrm{and} \mathrm{beaches} \mathrm{are} \mathrm{rela-}$ tively well preserved with minimal development pressures.

This study aimed to understand for the first time the internesting and postnesting movements of females tracked from an endangered and severely depleted rookery located in Brazil.

\section{MATERIALS AND METHODS}

Projeto TAMAR-ICMBio, the Brazilian Sea Turtle Conservation Program, has been working on the northern coast of the state of Espírito Santo since 1982, initially at Comboios and later gradually extending its activities northward. Since 1991, between 1 October and 31 January the entire leatherback nesting area has been patrolled daily at dawn by local fishermen, as well as by technical staff to record and protect nests, and during the peak of the season at night to tag nesting turtles (Almeida \& Mendes 2007, Thomé et al. 2007).

Satellite transmitters (KiwiSat 101, Sirtrack) were attached to 3 nesting leatherback females during the 2005-2006 nesting season. One additional female

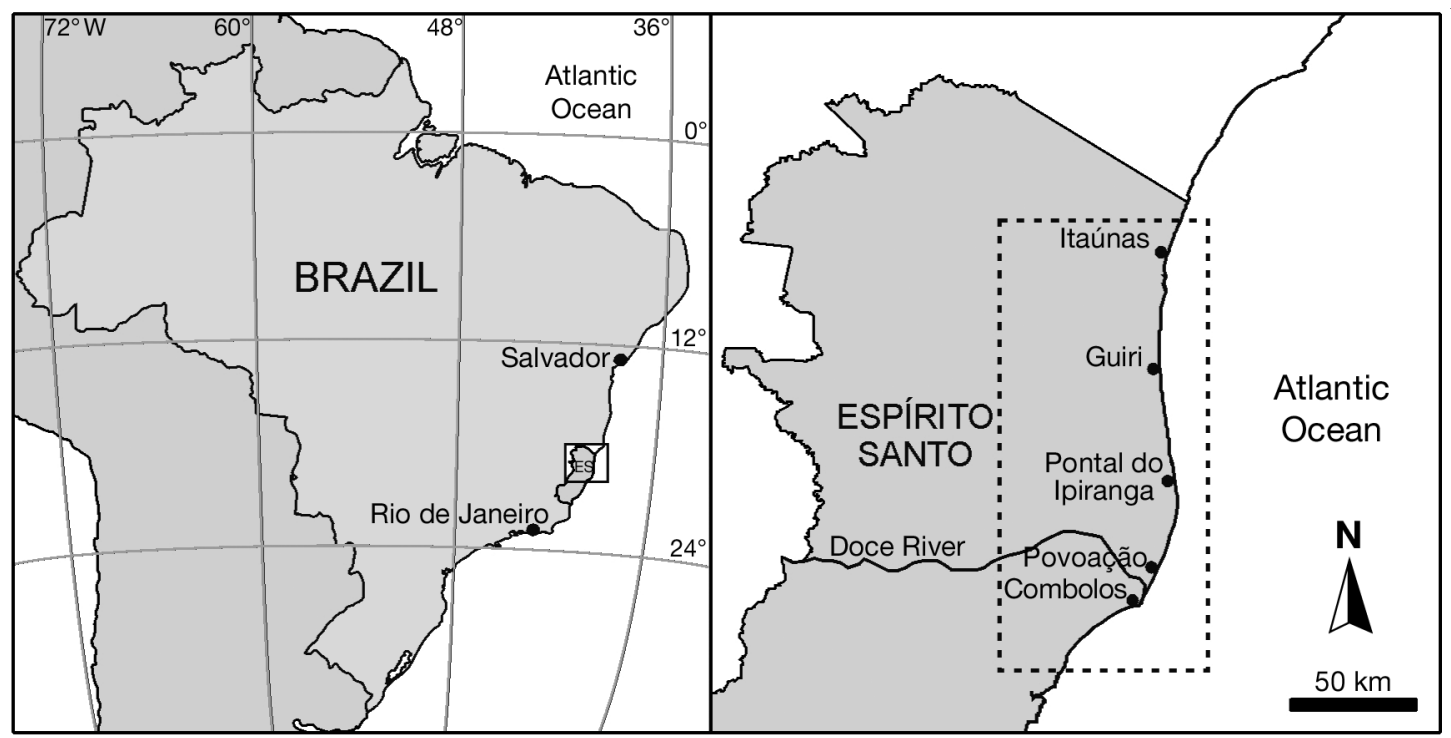

Fig. 1. Dermochelys coriacea. Nesting area in the state of Espírito Santo (ES) in southeastern Brazil (dashed rectangle) 
was satellite tagged on 12 February 2006 (also during the nesting season) after capture in a driftnet, ca. $200 \mathrm{~km}$ off the coast of the state of São Paulo (24도 $59^{\prime} \mathrm{S}, 44^{\circ} 31^{\prime} \mathrm{W}$ ) (Table 1 ).

Transmitters were powered by $4 \mathrm{C}$-size lithium batteries ( $0.5 \mathrm{~W}$ output), and were configured to transmit continuously upon surfacing during the first $30 \mathrm{~d}$ of deployment, and $24 \mathrm{~h}$ on $/ 48 \mathrm{~h}$ off after this period. Transmissions, processed via Argos (http:// argosinc.com), reported location information, surface temperature at the time of transmission, battery voltage, and number and duration of transmissions. Each transmitter was attached to a flexible harness using standard methods that have been used in many previous leatherback satellite tracking studies (e.g. Eckert et al. 1989, 2006, James et al. 2005a,b, Eckert 2006, Benson et al. 2007b, Hitipeuw et al. 2007, Shillinger et al. 2010).

Each turtle was measured with flexible plastic tapes (curved carapace length and width) and tagged with inconel tags (National Band and Tag Co.) in both rear flippers. Other data, such as date, time, and location, were also collected.

We located turtles through the Argos system with geolocations being categorized into 7 location classes $(3,2,1,0, A, B$, and Z). Location classes (LCs) 3, 2, and 1 are categorized to lie within $150 \mathrm{~m}, 150-350 \mathrm{~m}$, or 350-1000 m, respectively, of the tag's true position, while LCs $0, \mathrm{~A}$, and B have no location error estimate. Location data provided by Argos were downloaded and analyzed in the Satellite Tracking and Analysis Tool (STAT; Coyne \& Godley 2005), including data on bathymetry associated with the turtles' positions. Routes were reconstructed using LC 1-3 positions and filtered Argos positions LC 0 and $\mathrm{A}$ based on a maximum rate of travel of $5 \mathrm{~km} \mathrm{~h}^{-1}$. Geographic information systems software (ArcGis 9.1, ESRI) was used to map turtle movements and calculate high-use areas. To define important habitats for each turtle, we calculated fixed kernel home ranges using Hawth's Analysis Tools for ArcGIS
(Beyer 2004). High-use areas were defined using $50 \%$ utilization distribution (UD) of kernel home range estimation (KHRE; Eckert et al. 2006). To reduce temporal autocorrelation and sampling bias, data sets were filtered using the best single location per day, and the internesting period data were assessed separately from postnesting period data. Additional information from direct observations recorded during beach patrolling was used to complement information regarding internesting behavior.

\section{RESULTS}

Transmitters were attached to 3 females in Linhares, northern Espírito Santo (Table 1), on 13 to 15 December, during the peak of the nesting season. The nesters (Dc1-3) were tracked for 26, 388, and $409 \mathrm{~d}$, respectively. A fourth leatherback female (Dc4) was tagged around $200 \mathrm{~km}$ off the southeastern Brazilian coast and was tracked for $97 \mathrm{~d}$ (Table 1). This turtle (Dc4) received the transmitter recovered from Dc1, who had been killed earlier in a coastal gillnet.

\section{Internesting movements}

The 3 females tagged at Espírito Santo nesting beaches returned to nest at least once after transmitter deployment (Table 2). The fourth female (Dc4) was tagged at sea and did not nest while being tracked.

No patterns were evident among movements between individual consecutive nesting attempts, except that all turtles re-nested along different sections of the coast at each nesting (Fig. 2, Table 2).

After satellite tag deployment, Dc1 (Fig. 2A) traveled in a loop ca. $150 \mathrm{~km}$ offshore and returned to nest $13 \mathrm{~d}$ after deployment. This turtle then moved

Table 1. Dermochelys coriacea. Deployment and tracking information for leatherback turtles equipped with satellite transmitters at nesting beaches in Espírito Santo and off the coast of São Paulo, Brazil, from December 2005 to January 2007. CCL: curved carapace length. Dates given in $\mathrm{dd} / \mathrm{mm} / \mathrm{yy}$

\begin{tabular}{|c|c|c|c|c|c|c|c|c|}
\hline $\begin{array}{l}\text { Turtle } \\
\text { ID }\end{array}$ & $\begin{array}{l}\text { Turtle } \\
\text { tags }\end{array}$ & $\begin{array}{l}\text { CCL } \\
(\mathrm{cm})\end{array}$ & $\begin{array}{l}\text { Deployment } \\
\text { location }\end{array}$ & $\begin{array}{c}\text { Deployment } \\
\text { date }\end{array}$ & $\begin{array}{c}\text { Date of } \\
\text { last location }\end{array}$ & $\begin{array}{l}\text { Days } \\
\text { tracked }\end{array}$ & $\begin{array}{l}\text { Minimum distance } \\
\text { traveled }(\mathrm{km})\end{array}$ & $\begin{array}{c}\text { End battery } \\
\text { voltage }(\mathrm{mA})\end{array}$ \\
\hline Dc1 & BR 48825/ 48833 & 156 & Pontal do Ipiranga & $13 / 12 / 05$ & 08/01/06 & 26 & 1868 & 62 \\
\hline Dc2 & BR $48540 / 48544$ & 155 & Comboios & $15 / 12 / 05$ & $05 / 01 / 07$ & 388 & 15982 & 40 \\
\hline Dc3 & BR 48549/48550 & 153 & Comboios & $15 / 12 / 05$ & $28 / 01 / 07$ & 409 & 12698 & 35 \\
\hline Dc4 & BR 49147/49148 & 153 & Off São Paulo & $12 / 02 / 06$ & $20 / 05 / 06$ & 97 & 4165 & 18 \\
\hline
\end{tabular}


Table 2. Dermochelys coriacea. Nesting activity information recorded for the 3 leatherbacks tagged in December 2005 at the nesting beaches in the state of Espírito Santo, Brazil. Deployment dates (as dd/mm/yy) are in bold; time intervals are in days. $(-)$ indicates first record of an individual in the season

\begin{tabular}{|c|c|c|c|c|c|c|c|}
\hline Turtle & $\begin{array}{l}\text { Nesting } \\
\text { date }\end{array}$ & $\begin{array}{c}\text { Record } \\
\text { location } \\
\text { (beach zone) }\end{array}$ & $\begin{array}{c}\text { Distance from } \\
\text { last landings } \\
(\mathrm{km})\end{array}$ & $\begin{array}{l}\text { Record } \\
\text { type }\end{array}$ & $\begin{array}{l}\text { Interval between } \\
\text { consecutive records }\end{array}$ & $\begin{array}{l}\text { Interval between 1st } \\
\text { and last records }\end{array}$ & $\begin{array}{c}\text { Maximum spatial } \\
\text { interval between } \\
\text { nests }(\mathrm{km})\end{array}$ \\
\hline \multirow[t]{4}{*}{ Dc1 } & $11 / 11 / 05$ & 46 & - & Nest & - & \multirow[t]{4}{*}{57} & \multirow[t]{4}{*}{66} \\
\hline & 13/12/05 & 96 & 50 & Nest & 32 & & \\
\hline & 26/12/05 & 31 & 65 & Nest & 13 & & \\
\hline & 07/01/06 & 30 & 1 & False nest & 12 & & \\
\hline \multirow[t]{3}{*}{ Dc2 } & 04/11/05 & 33 & - & Nest & - & \multirow[t]{3}{*}{53} & \multirow[t]{3}{*}{46} \\
\hline & $15 / 12 / 05$ & 24 & 9 & Nest & 41 & & \\
\hline & $27 / 12 / 05^{\mathrm{a}}$ & 70 & 46 & Nest & 12 & & \\
\hline \multirow[t]{7}{*}{ Dc3 } & 05/11/05 & 25 & - & Nest & - & \multirow[t]{7}{*}{73} & \multirow[t]{7}{*}{36} \\
\hline & $25 / 11 / 05$ & 31 & 6 & Nest & 20 & & \\
\hline & 05/12/05 & 27 & 4 & Nest & 10 & & \\
\hline & $15 / 12 / 05$ & 28 & 1 & Nest & 10 & & \\
\hline & $27 / 12 / 05$ & 61 & 33 & Nest & 12 & & \\
\hline & $06 / 01 / 06^{\mathrm{a}}$ & 40 & 21 & Nest & 10 & & \\
\hline & $17 / 01 / 06$ & 42 & 1 & Nest & 11 & & \\
\hline
\end{tabular}

south, in a new loop that reached ca. $80 \mathrm{~km}$ offshore and emerged $12 \mathrm{~d}$ later in a false attempt to nest. On the next day (8 January), the turtle died entangled in a coastal gillnet in the mouth of the Doce River, $26 \mathrm{~d}$ after deployment. The turtle was entangled by the front flipper, and apparently the harness did not contribute to the entanglement. Necropsy revealed eggs, indicating that further nesting activity could have been possible. Data from beach patrols and observed internesting intervals suggested that this turtle had nested 5 times (Table 2) before entanglement. Dc1's in-water latitudinal internesting movements far exceeded the limits of the nesting area, comprising more than $300 \mathrm{~km}$. The total distance traveled was $1281 \mathrm{~km}$ during the internesting period, and the maximum distance from the coast was $161.6 \mathrm{~km}$. The high-use area comprised $4443 \mathrm{~km}^{2}$ (50\% KHRE).

Dc2 (Fig. 2B) moved ca. $56 \mathrm{~km}$ offshore, then headed south close to the municipality of Anchieta, and thereafter turned northward, looping very close to the coast. At the latitude of the Doce River mouth, the turtle headed west, meandering in a loop over 10 to $20 \mathrm{~km}$ from the shoreline, and then moved southward, heading to the coast around the southern limit of the nesting area; from this point, the turtle moved northward, navigating very close to the shoreline, for ca. $90 \mathrm{~km}$, emerging to the last nest on 27 December, $46 \mathrm{~km}$ away from its first nest site. The total distance traveled was $724.3 \mathrm{~km}$ during the internesting period, and the maximum distance from the coast was $71.7 \mathrm{~km}$. The high-use area comprised $2667 \mathrm{~km}^{2}$ (50\% KHRE).

Turtle Dc3, which received the transmitter on the same day as Dc2, showed more coastal movements (Fig. 2C), reaching ca. $50 \mathrm{~km}$ from the coast. Despite some meandering movements at the northern limit of the nesting area, this turtle stayed mostly in the southern nesting area and nested 3 times after deployment. Beach patrol data closely agree with the telemetry data and show that the turtle laid nests over a $73 \mathrm{~d}$ timeframe in the southern region. Nests were distributed as far as $36 \mathrm{~km}$ apart (Table 2). The total distance traveled was $1038.7 \mathrm{~km}$ during the internesting period, and the maximum distance from the coast was $53.1 \mathrm{~km}$. The high-use area comprised $438.5 \mathrm{~km}^{2}$ (50\% KHRE).

Movements of female leatherbacks ranged from 40 to $118 \mathrm{~km} \mathrm{~d}^{-1}$ (mean) between nesting events. All turtles reached the shelf break, and the movements of Dc1 ranged along the $2000 \mathrm{~m}$ isobath (Fig. 2A). The total area, as delineated by the $75 \%$ UD, was centered at the Doce River and extended offshore $60 \mathrm{~km}$ and $150 \mathrm{~km}$ to either side of the nesting area, comprising $4941 \mathrm{~km}^{2}$. The high-use area as described by the $50 \%$ UD was also centered at the Doce River mouth, and extended over a $50 \mathrm{~km}$ radius offshore and to each side along the coast, comprising $1170 \mathrm{~km}^{2}$ (Fig. 3). The overall $25 \%$ UD corresponded to $356.5 \mathrm{~km}^{2}$. 


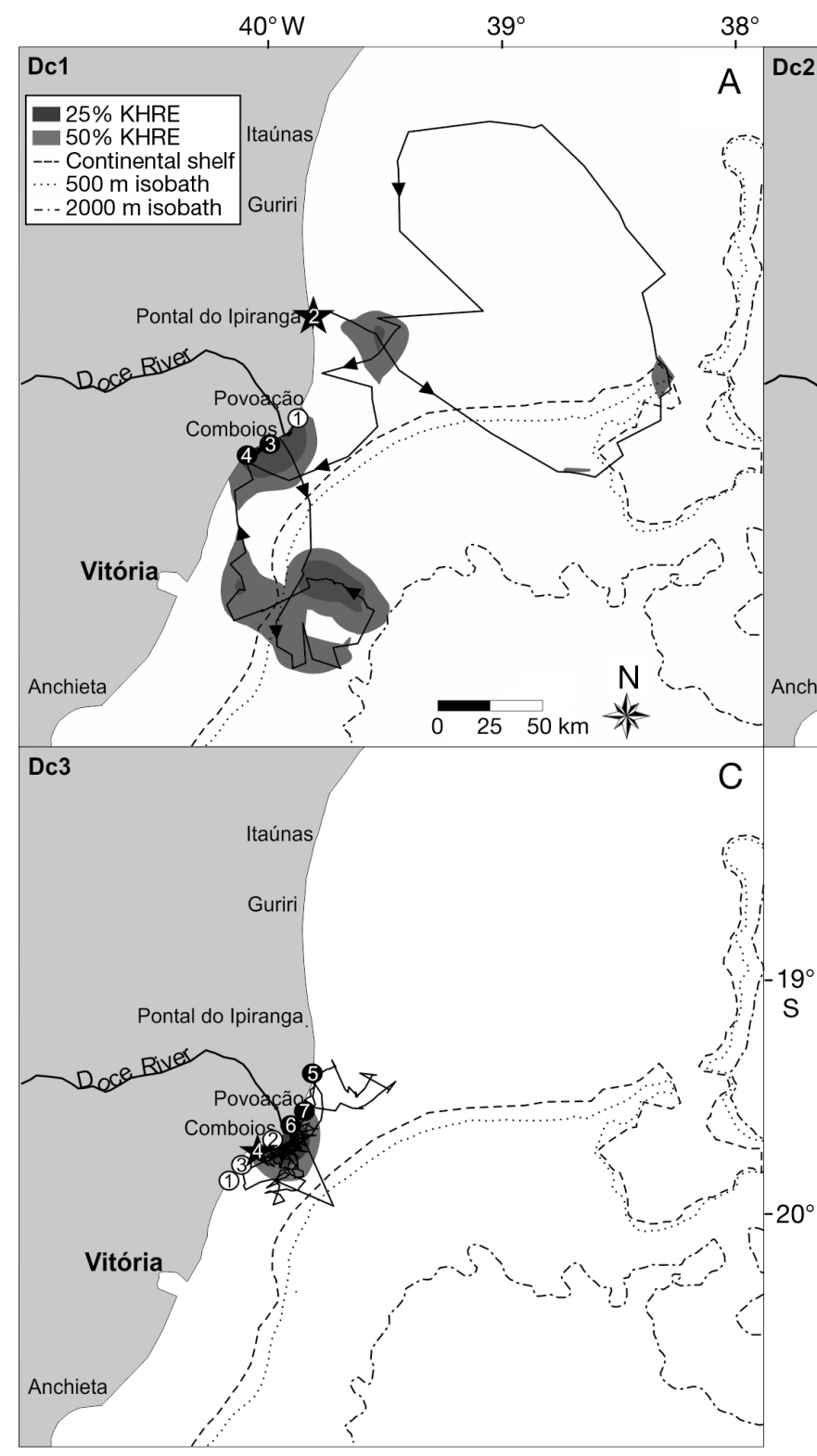

\section{Postnesting movements}

At the end of the nesting season, Dc2 and Dc3 started their migration southward. Dc2 moved offshore to oceanic waters before turning west and traveling $57 \mathrm{~d}$ to the coast of the State of Rio Grande do Sul; the turtle arrived on 23 February 2006 and remained for $50 \mathrm{~d}$. After that, Dc2 moved south to waters off Uruguay, arriving on 15 April and spent $15 \mathrm{~d}$ there before moving northward to the state of São Paulo, which she reached on 3 June. The turtle then moved east on a $6775 \mathrm{~km}$ transoceanic journey that lasted $216 \mathrm{~d}$, and reached waters $350 \mathrm{~km}$ off the coast of Angola, when transmissions ceased (Fig. 4A).
Fig. 2. Dermochelys coriacea. Internesting movements of 3 leatherbacks tagged in 2005 from nesting grounds in Espírito Santo, Brazil, and individual kernel estimated home range utilization distributions (KHRE); circles with numbers indicate successive nest locations; star, deployment site; white circles, nests prior to deployment. (A) turtle Dc1, (B) turtle Dc2, (C) turtle Dc3
Dc3 moved south along the continental shelf over a period of $72 d$, reaching the Rio de la Plata estuary, between Uruguay and Argentina, on 31 March 2006. After $55 \mathrm{~d}$ of residence in the estuary, the turtle moved northward for $93 \mathrm{~d}$ (starting on 25 May) towards the coast off the state of São Paulo (26 August). Following a $151 \mathrm{~d}$ gap in satellite transmissions, locations were again reported from the La Plata estuary on 26 January 2007 (Fig. 4B). These final transmissions lasted only $3 \mathrm{~d}$.

Dc4, tagged after capture in the driftnet fishery on 12 February 2006, moved eastward to oceanic waters $600 \mathrm{~km}$ from the coast, and then moved northward, reaching the coast of the state of Rio de Janeiro on 21 


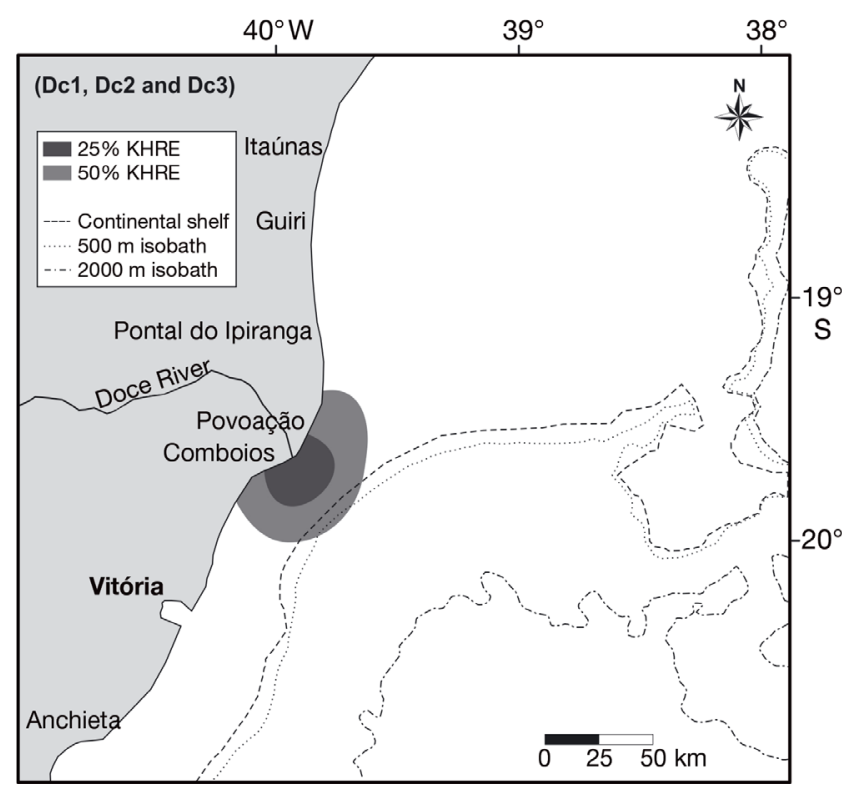

Fig. 3. Dermochelys coriacea. Joined kernel estimated home range utilization distributions (25 and $50 \%$ KHRE) of internesting locations for the 3 female leatherback turtles (Dc1-3) tracked by satellite telemetry from nesting beaches in northern State of Espírito Santo, Brazil, in 2005

March, from where she moved along the shelf to the coast of the state of Bahia on 14 May, and then southward to the coast of the state of Espírito Santo, when transmissions ceased after $97 \mathrm{~d}$ on 20 May (Fig. 4C).

The postnesting kernel utilization distribution for the 2 turtles tracked from nesting grounds (Dc 2 and Dc3, Fig. 5) highlights the presence of a large highuse area $\left(50 \%\right.$ UD $=206816 \mathrm{~km}^{2} ; 25 \%$ UD = $55780 \mathrm{~km}^{2}$ ) located along the southeastern and southern Brazilian coast, with 2 visible sub-areas; the largest of these, ranging from the state of Rio Grande do Sul to the Rio de la Plata estuary, was located between Uruguay and Argentina and comprised $122339 \mathrm{~km}^{2}$; the other was between the states of São Paulo and Santa Catarina $\left(50 \%\right.$ UD $=78790 \mathrm{~km}^{2}$; $25 \% \mathrm{UD}=17188 \mathrm{~km}^{2}$ ).

\section{DISCUSSION}

Satellite telemetry studies on internesting movements of leatherbacks are available for different nesting populations in the Atlantic Ocean: French Guyana, Grenada, Trinidad, Gabon, and Florida, USA (Eckert 2002, 2006, Eckert et al. 2006, Georges et al. 2007, Witt et al. 2007). Internesting behavior of the turtles tracked from southeastern Brazil was sim- ilar to those studies. Foraging by gravid leatherbacks during the internesting period is still controversial, despite increasing evidence from different leatherback populations (Eckert et al. 1989, Myers \& Hays 2006, Fossette et al. 2007, 2008). In the eastern Pacific, Shillinger et al. (2010) reported an internesting high-use area for females from Costa Rica, comprising a high productivity zone, similar to that reported by Fossette et al. (2007) for French Guyana/ Suriname.

The Doce River mouth and adjacent waters were the most intensely used areas during the internesting period; 2 turtles moved southwards later, and highuse areas were also identified over the shelf break at the latitude of the city of Vitória. Garfield (1990) showed that between $20^{\circ}$ and $31^{\circ} \mathrm{S}$, the continuous Brazil Current is associated with eddies and meanders, and forms fronts west of the main stream. Also, the shelf break accurately locates the mean position of the near surface inshore Brazil Current front. Schmid et al. (1995) described the Vitória Eddy as a temporary oceanographic event related to seasonal upwelling which is influenced by the local topography and the Brazil Current. The presence of leatherbacks in mesoscale eddy systems, which are presumed to aggregate prey (see Eckert et al. 2009) has been reported from several areas (Luschi et al. 2003, Eckert 2006, Eckert et al. 2006, Gaspar et al. 2006, Hays et al. 2006, Doyle et al. 2008). Further joint analyses, involving a larger set of tracked turtles, will be developed to evaluate possible correlations between movements and the presence of these temporary eddies.

The distances between nesting events for individual turtles sometimes exceeded $60 \mathrm{~km}$ (Table 2) and were much greater than those reported in other studies (e.g. Gabon and Grenada; Georges et al. 2007, Witt et al. 2007). Differences in spatial coverage of different studies could explain such variation; Stewart (2007) showed that individual leatherbacks nesting on mainland areas can distribute their nests at a greater distance than insular nesting turtles. During the in-water movements, turtles were subject to incidental capture in coastal and oceanic fisheries; in fact, turtle Dc1 died after being caught in a gillnet in the mouth of the Doce River.

Leatherback distribution, both in-water and on nesting beaches, observed in this study surpassed the boundaries of REBIO Comboios, and reinforces the need to expand conservation areas to the north of the Doce River, both on land and at sea.

Several satellite telemetry studies of leatherbacks have revealed prompt dispersion far from coastal 


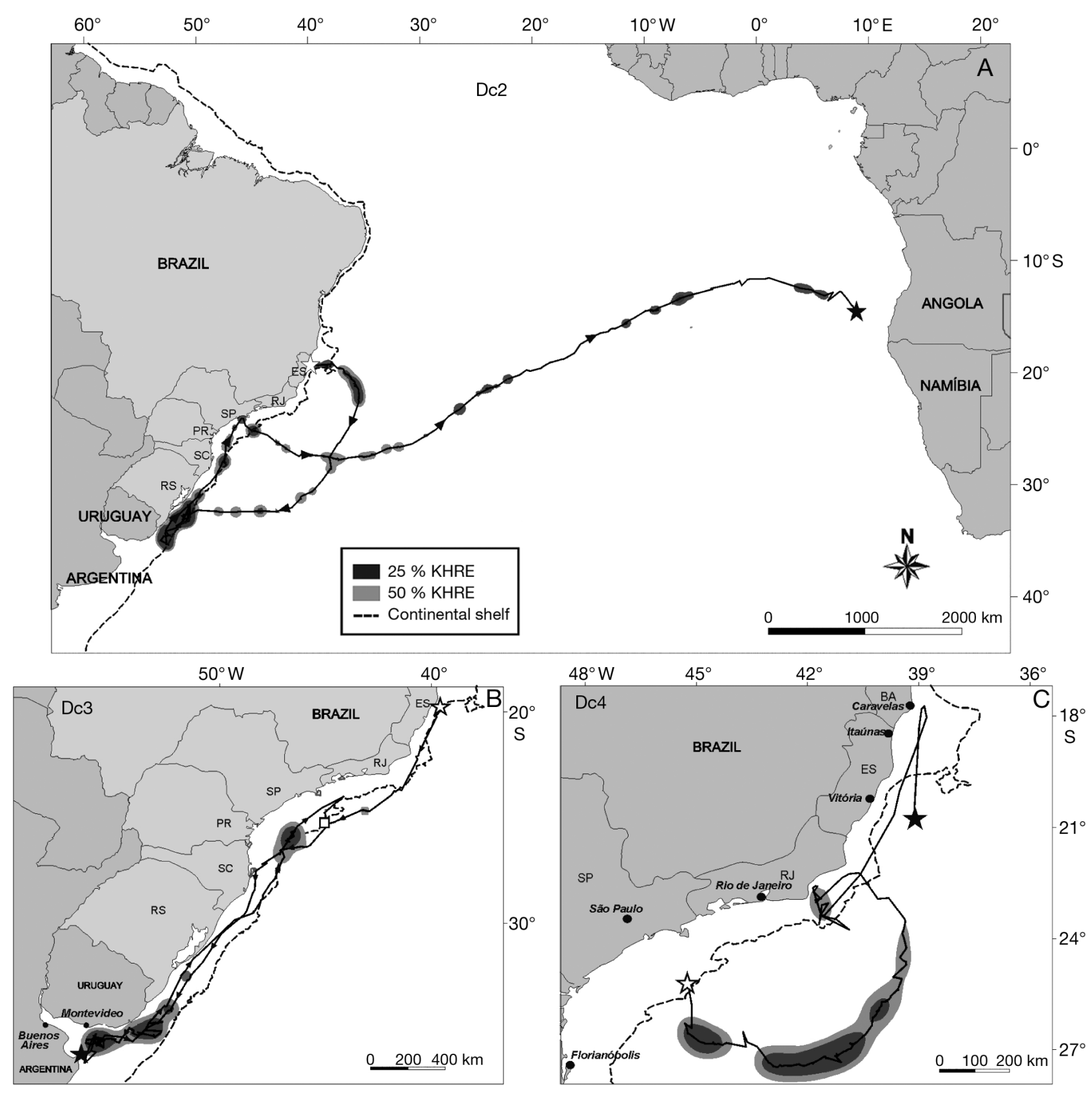

Fig. 4. Dermochelys coriacea. Kernel estimated home range utilization distributions (25 and $50 \%$ KHRE) and migratory paths of 2 postnesting female leatherbacks tracked from Espírito Santo, Brazil, and 1 female leatherback caught in a drift net off the State of São Paulo, Brazil. Open stars indicate tracking starting point; black stars show last transmission. (A) turtle Dc2; (B) turtle Dc3: square, starting point of a 151 d interruption; (C) turtle Dc4. State abbreviations - ES: Espírito Santo; RJ: Rio de Janeiro; SP: São Paulo; PR: Paraná; SC: Santa Catarina; RS: Rio Grande do Sul

waters after nesting (e.g. Eckert \& Sarti 1997, Eckert 1998, Hughes et al. 1998, Hays et al. 2004, Benson et al. 2007b, Shillinger et al. 2008), to temperate feeding grounds (James et al. 2005a,b, Eckert et al. 2006, Benson et al. 2007b), where jellyfish show greatest abundances (Houghton et al. 2006), or to tropical oceanic patchy areas of elevated productivity (Fer- raroli et al. 2002, Eckert 1998, 2006, Eckert et al. 2006, Fossette et al. 2010).

An exception to this exclusively oceanic pattern was reported by Eckert et al. (2006), whose tracked turtles undertook coastal migrations along the North American continental shelf to reach foraging grounds located off northern USA/southern Canada. 


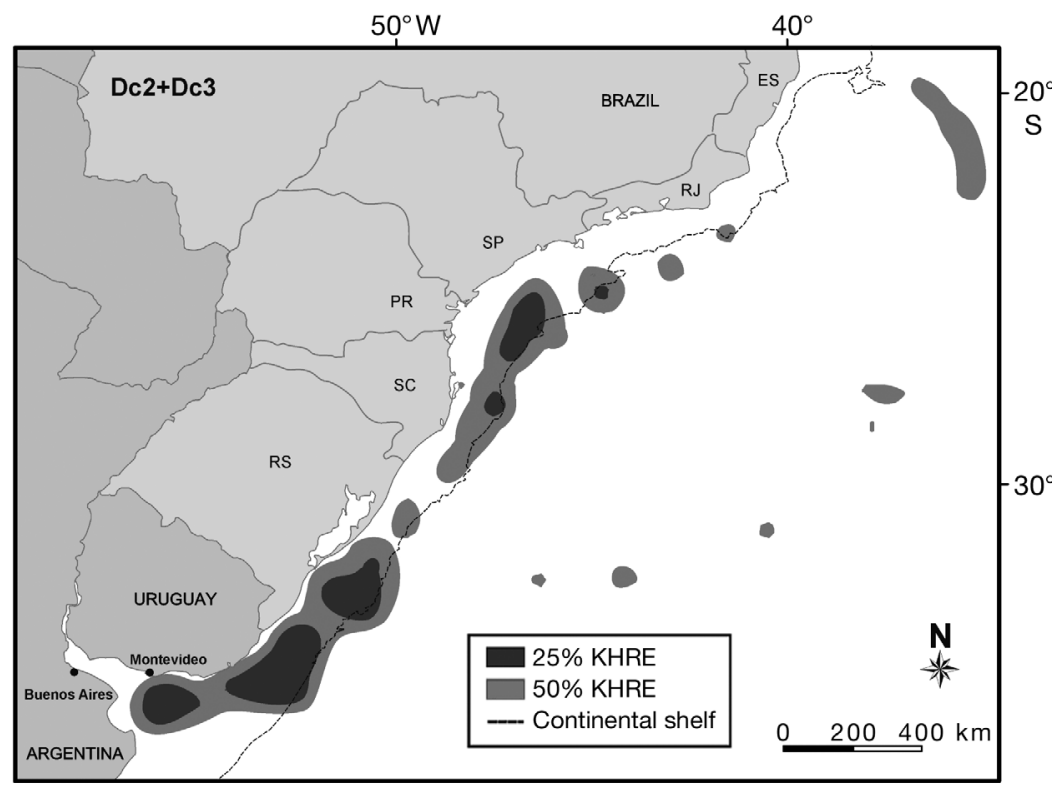

Fig. 5. Dermochelys coriacea. Joined kernel estimated home range utilization distributions (KHRE) of postnesting locations for 2 female leatherback turtles tracked by satellite telemetry from nesting beaches in northern state of Espírito Santo and 1 turtle caught in a drift net off the state of São Paulo

of great concern: the high number of turtles killed by incidental capture in gillnets and driftnets (Billes et al. 2006, Fiedler 2009) and the relatively high incidental capture rates reported from the Brazilian longline fishery operating along the entire migration routes delineated (Sales et al. 2008) threaten both populations. In fact, the high number of leatherbacks stranded in Brazil cannot be accounted for by the small number of leatherbacks nesting in Brazil, and so must include turtles from distant nesting colonies (Barata et al. 2004, Sales et al. 2008). Telemetry results of Witt et al. (2011) suggest the large Gabon nesting colony as the main origin of strandings in southern Brazil. Further studies, involving more refined genetic approaches comprising both nesting and foraging leatherbacks from South America and Africa, will certainly improve our under-

Some of the tracked turtles, however, traveled from this feeding ground to oceanic areas. Leatherbacks tracked from nesting grounds in Brazil seem to fit this pattern, moving to a high-latitude temperate foraging area, after traveling along the continental shelf. One of the turtles also undertook a transoceanic migration, heading to the African coast.

Despite the few turtles tracked, the extended duration (15 to 55 d) in the Rio de la Plata estuary and waters adjacent to Uruguay and Argentina supports previous studies that identify the region as an important foraging area for leatherbacks in the Southwest Atlantic (López-Mendilaharsu et al. 2009) and suggests that this region is frequented by the Brazilian population. In fact, 1 leatherback tagged at Brazilian nesting grounds was found stranded in Argentina (Alvarez et al. 2009), corroborating this assumption. The origin of the turtle tracked after being incidentally captured off the state of São Paulo is unknown. Vargas et al. (2008) provided evidence of multiple genetic stocks involving leatherbacks stranded or incidentally captured in southern Brazil. Tag recoveries also showed that turtles tagged at nesting sites in Gabon reached waters off southern Brazil and Argentina (Billes et al. 2006). Witt et al. (2011) also reported migrations of postnesting leatherbacks from Gabon to the same region. Thus, the presence of turtles from at least 2 different nesting populations in the area is a matter standing of the relationships amongst these populations and will drive the needed conservation efforts.

Our results reinforce the importance of the Doce River Coastal Plain, previously reported by Thomé et al. (2007), including adjacent waters that surpass the continental nesting limits. Measures must be taken to guarantee spatial integrity that allows both the establishment of several proposed industrial activities and the conservation of this endangered leatherback nesting population in southeastern Brazil. Therefore, the proposal for a new Federal Conservation Area, comprising the nesting area situated in the north of the Doce River mouth, as well as the mitigation of the impacts of both oceanic and coastal fisheries in southeastern and southern Brazil, are urgent measures for the conservation of the severely depleted nesting leatherback population of southeastern Brazil. The effects of these measures will also contribute to protect the largest known leatherback population from Gabon.

Acknowledgements. We are indebted to TAMAR staff and volunteers involved in beach patrolling to allow the deployment of transmitters in nesting females. We thank the crews of the vessels 'Soloncy Moura,' from CEPSUL-ICMBio, for their dedication, and the fisher 'Nieves' for the help in providing the incidentally caught leatherback. We also thank J. Spotila, F. Paladino, R. Reina, B. Wallace, G. Shillinger, and P. Tomillo for allowing A.P.A. to learn the harness deployment techniques at Playa Grande. A.P.A. also thanks K. Eck- 
ert, D. Dunn, and W. Dow, from WIDECAST, for their kindness and hospitality during data analysis training. This study was part of the Sea Turtle Biology Study Program, funded by PETROBRAS Research Center - CENPES/PETROBRAS. Projeto TAMAR is affiliated with ICMBio (the Brazilian Institute for the Conservation of Biodiversity), co-managed by Fundação Pró-TAMAR, and officially sponsored by PETROBRAS.

\section{LITERATURE CITED}

Almeida AP, Mendes SL (2007) An analysis of the role of local fishermen in the conservation of the loggerhead turtle (Caretta caretta) in Pontal do Ipiranga, Linhares, ES, Brazil. Biol Conserv 134:106-112

Alvarez KC, Diaz L, Almeida AP, Rodriguez-Heredia SA (2009) Recuperación de marcas en la costa norte de la provincia de Buenos Aires, Argentina. Libro de Resúmenes del IV Jornadas de Conservación e Investigación de Tortugas Marinas del Atlántico Sur Ocidental (ASO). Mar del Plata, Buenos Aires, Argentina, 30 de Setembro a 01 de Outubro de 2009, p 166-167

Barata PCR, Lima EHSM, Borges-Martins M, Scalfoni JT, Bellini C, Siciliano S (2004) Records of the leatherback sea turtle (Dermochelys coriacea) on the Brazilian coast, 1969-2001. J Mar Biol Assoc UK 84:1233-1240

> Benson SR, Kisokau KM, Ambio L, Rei V, Dutton PH, Parker D (2007a) Beach use, internesting movement, and migration of leatherback turtles, Dermochelys coriacea, nesting on the north coast of Papua New Guinea. Chelonian Conserv Biol 6:7-14

> Benson SR, Dutton PH, Hitipeuw C, Samber B, Bakarbessy J, Parker D (2007b) Post-nesting migrations of leatherback turtles (Dermochelys coriacea) from Jamursba-Medi, Bird's Head Peninsula, Indonesia. Chelonian Conserv Biol 6:150-154

Beyer HL (2004) Hawth's analysis tools for ArcGIS. Available at www.spatialecology.com/htools

Billes A, Fretey J, Verhage B, Huijbregts B and others (2006) First evidence of leatherback movement from Africa to South America. Mar Turtle Newsl 111:13-14

> Chacón-Chaverri D, Eckert KL (2007) Leatherback sea turtle nesting at Gandoca Beach in Caribbean Costa Rica: management recommendations from fifteen years of conservation. Chelonian Conserv Biol 6:101-110

Coyne MS, Godley BJ (2005) Satellite Tracking and Analysis Tool (STAT): an integrated system for archiving, analyzing and mapping animal tracking data. Mar Ecol Prog Ser 301:1-7

> Doyle TK, Houghton JDR, O'Súilleabháin PF, Hobson VJ, Marnell F, Davenport J, Hays GC (2008) Leatherback turtles satellite-tagged in European waters. Endang Species Res 4:23-31

Dutton DL, Dutton PH, Chaloupka M, Boulon RH (2005) Increase of a Caribbean leatherback turtle Dermochelys coriacea nesting population linked to long-term nest protection. Biol Conserv 126:186-194

Eckert SA (1998) Perspectives on the use of satellite telemetry and other electronic technologies for the study of marine turtles, with reference to the first year-long tracking of leatherback turtles. In: Epperly SP, Braun J (eds) Proc 17th Symp Sea Turtle Biol Conserv. NOAA Tech Memo NMFS-SEFSC-415. US Department of Commerce, Orlando, FL, p 44-46
Eckert SA (2002) Swim speed and movement patterns of gravid leatherback turtles (Dermochelys coriacea) at St. Croix, U.S. Virgin Islands. J Exp Biol 205: 3689-3697

- Eckert SA (2006) High-use oceanic areas for Atlantic leatherback sea turtles (Dermochelys coriacea) as identified using satellite telemetered location and dive information. Mar Biol 149:1257-1267

Eckert SA, Sarti L (1997) Distant fisheries implicated in the loss of the world's largest leatherback nesting population. Mar Turtle Newsl 78:2-7

$>$ Eckert SA, Eckert KL, Ponganis P, Kooyman GL (1989) Diving and foraging behavior of leatherback sea turtles (Dermochelys coriacea). Can J Zool 67:2834-2840

> Eckert SA, Bagley D, Kubis S, Ehrhart L, Johnson C, Stewart K, DeFreese D (2006) Internesting and postnesting movements and foraging habitats of leatherback sea turtles (Dermochelys coriacea) nesting in Florida. Chelonian Conserv Biol 5:239-248

Eckert KL, Wallace BP, Frazier JG, Eckert SA, Pritchard PCH (2009) Synopsis of the biological data on the leatherback sea turtle, Dermochelys coriacea (Vandelli, 1761). US Fish and Wildlife Service PO no. 20181-0-0169, Jacksonville, FL

Ferraroli S, Eckert SA, Chevalier J, Girondot M, Kelle L, Maho YL (2002) Marine behavior of leatherback turtles nesting in French Guiana for conservation strategy. In: Mosier A, Foley A, Brost B (comps) Proc 20th Symp Sea Turtle Biol Conserv. NOAA Tech Memo NMFS-SEFSC477, Miami, FL

Fiedler FN (2009) As pescarias industriais de rede de emalhe de superficie e as tartarugas marinhas: caracterização das frotas de Itajaí, Navegantes, Porto Belo (Santa Catarina) e Ubatuba (São Paulo), suas áreas de atuação, sazonalidade e a interação com as tartarugas marinhas. MSc thesis, Universidade Federal do Paraná, Curitiba

> Fossette S, Ferraroli S, Tanaka H, Ropert-Coudert Y and others (2007) Dispersal and dive patterns in gravid leatherback turtles during the nesting season in French Guiana. Mar Ecol Prog Ser 338:233-247

> Fossette S, Kelle L, Girondot M, Goverse E and others (2008) The world's largest leatherback rookeries: conservation and research in French Guiana and Gabon. J Exp Mar Biol Ecol 356:69-82

> Fossette S, Girard C, López-Mendilaharsu M, Miller P and others (2010) Atlantic leatherback migratory paths and temporary residence areas. PLoS ONE 5:e13908

Fretey J, Billes A, Tiwari M (2007) Leatherback, Dermochelys coriacea, nesting along the Atlantic coast of Africa. Chelonian Conserv Biol 6:126-129

Garfield N (1990) The Brazil Current at subtropical latitudes. PhD thesis, University of Rhode Island, Kingston

- Gaspar P, Georges JY, Fossette S, Lenoble A, Ferraroli S, Le Maho Y (2006) Marine animal behaviour: Neglecting ocean currents can lead us up the wrong track. Proc R Soc Lond B Biol Sci 273:2697-2702

> Georges JY, Fossette S, Billes A, Ferraroli S and others (2007) Meta-analysis of movements in Atlantic leatherback turtles during the nesting season: conservation implications. Mar Ecol Prog Ser 338:225-232

Girondot M, Godfrey MH, Ponge L, Rivalan P (2007) Modeling approaches to quantify leatherback nesting trends in French Guiana and Suriname. Chelonian Conserv Biol 6: $37-47$ 
Hays GC, Houghton JD, Myers AE (2004) Pan-Atlantic leatherback turtle movements. Nature 429:522

- Hays GC, Hobson VJ, Metcalfe JD, Righton D, Sims DW (2006) Flexible foraging movements of leatherback turtles across the North Atlantic Ocean. Ecology 87: 2647-2656

Hilterman ML, Goverse E (2007) Nesting and nest success of the leatherback turtle (Dermochelys coriacea) in Suriname, 1999-2005. Chelonian Conserv Biol 6:87-100

> Hitipeuw C, Dutton PH, Benson S, Thebu J, Bakarbessy J (2007) Population status and internesting movement of leatherback turtles, Dermochelys coriacea, nesting on the northwest coast of Papua, Indonesia. Chelonian Conserv Biol 6:28-36

> Houghton JDR, Doyle TK, Wilson MW, Davenport J, Hays GC (2006) Jellyfish aggregations and leatherback turtle foraging patterns in a temperate coastal environment. Ecology 87:1967-1972

Hughes GR, Luschi P, Mencacci R, Papi F (1998) The 7000$\mathrm{km}$ oceanic journey of a leatherback turtle tracked by satellite. J Exp Mar Biol Ecol 229:209-217

> James MC, Ottensmeyer CA, Myers RA (2005a) Identification of high-use habitat and threats to leatherback sea turtles in northern waters: new directions for conservation. Ecol Lett 8:195-201

James MC, Eckert SA, Myers RA (2005b) Migratory and reproductive movements of male leatherback turtles (Dermochelys coriacea). Mar Biol 147:845-853

James MC, Sherrill-Mix SA, Martin KE, Myers RA (2006a) Canadian waters provide critical foraging habitat for leatherback turtles. Biol Conserv 133:347-357

> James MC, Davenport J, Hays GC (2006b) Expanded thermal niche for a diving vertebrate: a leatherback turtle diving into near-freezing water. J Exp Mar Biol Ecol 335: 221-226

> López-Mendilaharsu M, Rocha CFD, Miller P, Domingo A, Prosdocimi L (2009) Insights on leatherback turtle movements and high use areas in the Southwest Atlantic Ocean. J Exp Mar Biol Ecol 378:31-39

> Luschi P, Sale A, Mencacci R, Hughes GR, Lutjeharms JRE, Papi F (2003) Current transport of leatherback sea turtles (Dermochelys coriacea) in the ocean. Proc Biol Sci 270 (Suppl 2):S129-S132

Martínez LS, Barragán AR, Muñoz DG, García N, Huerta P, Vargas F (2007) Conservation and biology of the leatherback turtle in the Mexican Pacific. Chelonian Conserv Biol 6:70-78

Morreale SJ, Standora EA, Spotila JR, Paladino FV (1996) Migration corridor for sea turtles. Nature 384:319-320

> Myers AE, Hays GC (2006) Do leatherback turtles Dermochelys coriacea forage during the breeding season? A combination of data-logging devices provide new insights. Mar Ecol Prog Ser 322:259-267

Ordoñez C, Troëng S, Meylan A, Meylan P, Ruiz A (2007) Chiriqui Beach, Panama, the most important leatherback nesting beach in Central America. Chelonian Conserv Biol 6:122-126

Editorial responsibility: Jeffrey Seminoff,

La Jolla, California, USA
Saba VS, Santidrian Tomillo P, Reina RD, Spotila JR, Musick JA, Evans DA, Paladino FV (2007) The effect of the El Niño Southern Oscillation on the reproductive frequency of eastern Pacific leatherback turtles. J Appl Ecol 44: 395-404

Saba VS, Spotila JR, Chavez FP, Musick JA (2008) Bottomup and climatic forcing on the worldwide population of leatherback turtles. Ecology 89:1414-1427

> Sales G, Giffoni B, Barata PCR (2008) Incidental catch of sea turtles by the Brazilian pelagic longline fishery. J Mar Biol Assoc UK 88:853-864

> Santidrián Tomillo PS, Vélez E, Reina RD, Piedra R, Paladino FV, Spotila JR (2007) Reassessment of the leatherback turtle (Dermochelys coriacea) nesting population at Parque Nacional Marino Las Baulas, Costa Rica: effects of conservation efforts. Chelonian Conserv Biol 6:54-62

Schmid C, Schafer H, Podestá G, Zenk W (1995) The Vitória Eddy and its relation to the Brazil Current. J Phys Oceanogr 25:2532-2546

Shillinger GL, Palacios DM, Bailey H, Bograd SJ and others (2008) Persistent leatherback turtle migrations present opportunities for conservation. PLoS Biol 6:e171

Shillinger GL, Swithenbank AM, Bograd SJ, Bailey H and others (2010) Identification of high-use internesting habitats for eastern Pacific leatherback turtles: role of the environment and implications for conservation. Endang Species Res 10:215-232

Spotila JR, Dunham AE, Leslie AJ, Steyermark AC, Plotkin PT, Paladino FV (1996) Worldwide population decline of Dermochelys coriacea: Are leatherback turtles going extinct? Chelonian Conserv Biol 2:209-222

> Spotila JR, Reina RD, Steyermark AC, Plotkin PT, Paladino FV (2000) Pacific leatherback turtles face extinction. Nature 405:529-530

Stewart KR (2007) Establishment and growth of a sea turtle rookery: the population biology of the leatherback in Florida. PhD dissertation, Duke University, Durham

Thomé JCA, Baptistotte C, Moreira LMP, Scalfoni JT, Almeida AP, Rieth DB, Barata PCR (2007) Nesting biology and conservation of the leatherback sea turtle (Dermochelys coriacea) in the state of Espírito Santo, Brazil, 1988-1989 to 2003-2004. Chelonian Conserv Biol 6: 15-27

- Vargas SM, Araújo FCF, Monteiro DS, Estima SC, Almeida AP, Soares LS, Santos FR (2008) Genetic diversity and origin of leatherback turtles (Dermochelys coriacea) from the Brazilian coast. J Hered 99:215-220

Witt MJ, Broderick AC, Johns DJ, Martin C, Penrose R, Hoogmoed MS, Godley BJ (2007) Prey landscapes help identify potential foraging habitats for leatherback turtles in the NE Atlantic. Mar Ecol Prog Ser 337: 231-243

Witt MJ, Bonguno EA, Broderick AC, Coyne MS and others (2011) Tracking leatherback turtles from the world's largest rookery: assessing threats across the South Atlantic. Proc R Soc Lond B Biol Sci 278:2338-2347

Submitted: May 31, 2010; Accepted: June 1, 2011

Proofs received from author(s): 